Ткач М. Я., канд. техн. наук, ст. наук. співроб. ${ }^{1}$

(0000-0002-8832-1268);

Бойко Р. В., канд. техн. наук, ст. наук. співроб. ${ }^{2}$

(0000-0001-7240-4299);

Лойшин А. А. ${ }^{1}$

(0000-0003-2769-9336);

Бойко В. О. канд. екон. наук, ст. наук. співроб. ${ }^{2}$

(0000-0002-3264-7111)

1 - Національний університет оборони України імені Івана Черняховського, Київ;

2 - Центр воєнно-стратегічних досліджень Національного університету оборони України імені Івана Черняховського, Київ

\title{
Рекомендації щодо фінансового та економічного забезпечення потреб національної оборони під час протидії гібридній війні
}

Резюме. У статті проведено аналіз економічного тиску як однієї зі складових гібридної війни Російської Федерації проти України. Розкрито сутність економічного тиску, який почався задовго до збройного конфлікту та доведено, що його головною метою була зупинка інтеграції України з СС і НАТО. Показано вплив збройної агресії та окупації частини територій України на ії макроекономічну стабільність. Розкрито проблематику економічного і фінансового забезпечення потреб національної оборони та надано пропозиції щодо ії удосконалення в умовах гібридної війни. безпека.

Ключові слова: гібридна війна; ресурси; фінансове та економічне забезпечення; рівень інфляції;

Постановка проблеми. Метою гібридної війни до сьогодні залишається досягнення державою-агресором певних стратегічних цілей [1]. Для цього використовується сукупність інструментів дипломатичних, економічних, воєнних, інформаційних та інших. Кожен 3 них, як правило, використовується одночасно у поєднанні 3 іншими. Незалежно від використання перелічених інструментів, головною особливістю гібридної війни $\epsilon$ домінування невоєнних компонентів під час вирішення стратегічних цілей.

Оскільки для протидії гібридній війні потрібні ресурси, а особливо фінансові, Російська Федерація (РФ) завчасно, до збройного конфлікту, почала використовувати економічний тиск на Україну, що призвело до значних втрат у національній економіці і, як наслідок, до значного зубожіння громадян, проживаючих на території України.

В умовах протидії гібридній війні та слабкої економіки України існує гостра необхідність удосконалення системи економічного i фінансового забезпечення національної оборони 3 урахуванням існуючого ресурсу та мінімізацією впливу на соціально-економічний розвиток країни.

Аналіз останніх досліджень. Сутність і зміст війн, збройних конфліктів належить до проблем, які в усі часи хвилювали відомих філософів, що й дістало своє теоретичне відображення у різноманітних концепціях цих мислителів.
Поняття “гібридна війна" сформувалося у працях американських воєнних аналітиків i керівників структур воєнного управління. Добре відомими донині $\epsilon$ роботи Ф. Хоффмана, Т. Губера, Б. Неметта, Дж. Мак Куена, Дж. Ласіка, у яких досліджується сучасний спосіб ведення воєнних кампаній, їх інформаційні, економічні, дипломатичні складники та їх зв'язок із досягненням кінцевих політичних цілей. Широке застосування способів і методів воєнних конфліктів гібридного типу для розв'язання міждержавних проблем на сучасному етапі розвитку людства спонукали вітчизняних науковців до поглибленого їх аналізу. Так, останнім часом дослідженню питань економічного впливу, як складової “гібридної війни” присвячені праці таких вітчизняних вчених, як В. Горбуліна, Е. Магди, О. Лещенка, В. Мунтіяна, I. Ткача. Аналіз їх досліджень дає змогу стверджувати, що виклики та загрози, які несе "гібридна війна", особливо на фінансово-економічну складову, постійно трансформуються, змінюють свою форму, характер та ознаки. Отже існує необхідність постійного моніторингу характеру зміни форм гібридної війни в контексті економічного і фінансового тиску країною агресором на iํ жертву. Адже гібридна війна, подібно до класичної, $є$ зіткненням двох (або більше) економік держав, і чим економіка витриваліша та готова до забезпечення потреб національної оборони, тим більше вірогідність перемогти агресора [1-6]. 
Метою статті є надання рекомендацій щодо фінансового i економічного забезпечення потреб національної оборони під час протидії “гібридній війні”.

Виклад основного матеріалу статті. Забезпечення потреб національної оборони здійснюється 3 державного бюджету України
[13], який залежить від стану національної економіки. Економічний тиск і збройна агресія 3 боку РФ призвели до значних втрат ВВП України та зменшили піi можливості фінансування заходів протидії "гібридній війні”, (рис. 1).

млрд дол.США

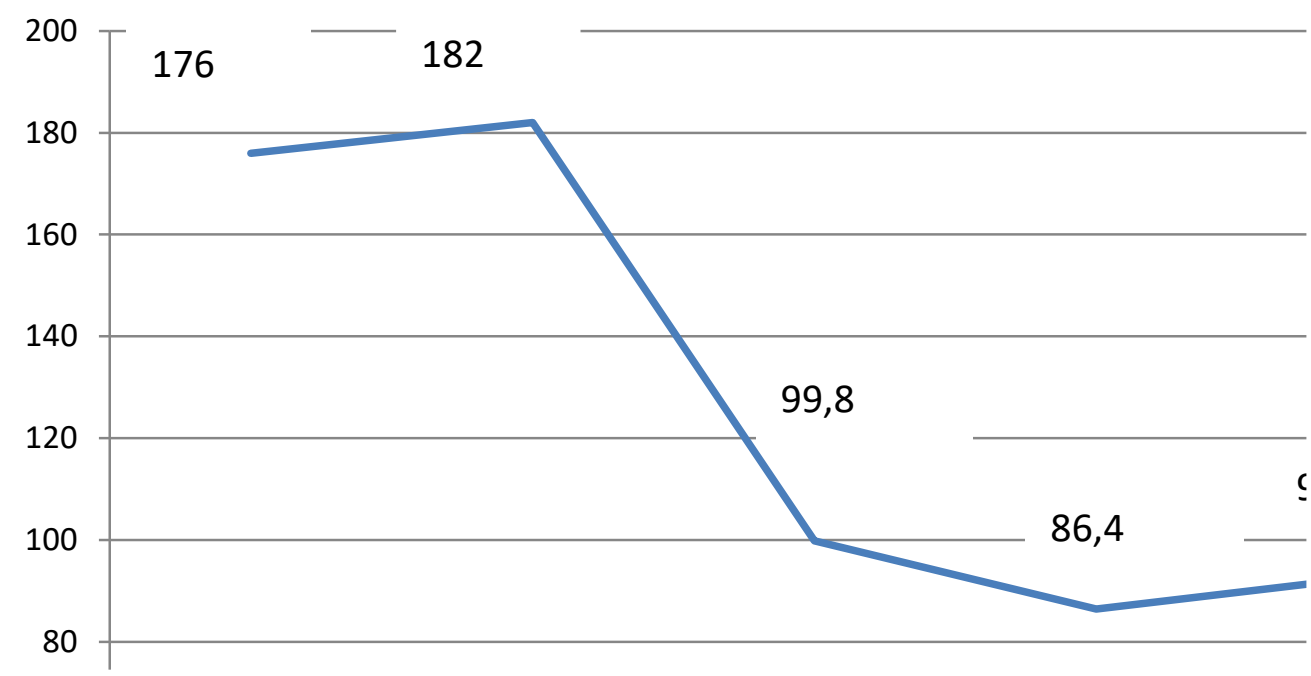

Рис. 1. Валовий внутрішній продукт України у 2012 - 2018 роках (млрд дол. США) [12]

2013 рік можна вважати початком відкритої та масштабної “економічної війни” РФ проти України, хоча і до цього відбувався економічний тиск з боку РФ у формі “газового шантажу” та інших торгових обмежень. У 2013 році Росія вводить санкції щодо поставок сталевих труб, запроваджено заборону на ввезення в РФ української кондитерської продукції, призупинено дію сертифікатів на вантажні вагони українського виробництва, запроваджено спеціальні мита на столовий посуд [3]. Головною метою був шантаж тодішньої державної влади України для припинення переговорів 3 підписання асоціації 3 Європейським Союзом (СС) та залученням України до Митного союзу.

У 2014 році РФ вводить додаткові обмеження щодо ввезення української продукції молокопереробної галузі, було заблоковано транзит через територію РФ українського цукру, обмежено можливості ввезення до РФ картоплі та кукурудзи. Підвищено вимоги митного контролю до всіх без винятку українських товарів, що спричинило затримку вантажів на кордоні та призвело до значних збитків для українських виробників.

У 2016 році РФ ввела ембарго на імпорт продовольства 3 України та відповідно до указу президента РФ було обмежено транзит через територію Росії українських товарів до країн середньої Азії [4].

Особливу увагу слід звернути на економічно-секторальні аспекти "гібридної війни” РФ проти України. Унаслідок розпаду Радянського Союзу, у якому національна економіка будувалася за принципом взаємозалежності союзних республік (сировина, комплектуючі, ланцюги поставок, готова продукція), РФ так і залишилася монополістом у постачанні деяких необхідних для української економіки товарів та основним споживачем деяких товарів окремих галузей економіки. Така залежність України поставила iii в дуже небезпечне становище і надала РФ широкий вибір напрямів економічного тиску.

Станом на 2012 рік Україна експортувала до РФ $52 \%$ товарів машинобудівної продукції, а імпортувала $13,8 \%$ від загального імпорту товарів машинобудівної галузі. Залежність РФ від українського експорту товарів, станом на 2012 рік, була більшою ніж України від російського імпорту. Більшу частина імпортних товарів машинобудівної продукції з РФ припадала на тепловидільні елементи для реакторів на АЕС. 3 початком війни, для зменшення залежності від поставок з РФ, було розширено співпрацю 
3 американською компанією Westinghouse [5].

У 2016 році 3 боку РФ було вжито економічні санкції через введення в дію указу президента РФ "Про припинення РФ дії Договору про зону вільної торгівлі щодо України", що вдарило зокрема по металургійній галузі України [6]. Експорт української металургійної продукції до РФ, станом на 2015 рік, становив 19,9\%, але 3 розірванням Договору збільшилося ввізне мито, що зробило українську продукцію менш конкурентоздатною на російському ринку.

Щодо енергетичної галузі України, то вона була і залишається основною сферою “економічної війни” РФ проти України. Для удару по енергетичній галузі України РФ застосовує всі можливі варіанти тиску, до яких можна віднести: інформаційний вплив (створення ілюзії у населення України, що без допомоги від РФ Україна не здатна забезпечити громадян електроенергією i теплом); фізичне захоплення чи руйнування об'єктів інфраструктури енергетичного сектору України (в окупованих районах Донецької i Луганської областей), економічний тиск; зовнішньополітичний вплив (міжнародні проєкти 3 будівництва газопроводів в обхід України).

Одним із головних напрямів гібридної війни РФ проти України на сьогодні можна вважати намагання позбавити Україну статусу головного транзитера природного газу до Європи. Для досягнення цієї мети РФ виділяє десятки мільярдів доларів, щоб забезпечити будівництво газопроводів в обхід України. Станом на 2019 рік РФ вже спорудила дві нитки “Турецького потоку” 3 потужністю 15,75 млрд куб. м газу кожна. Також завершується будівництво трубопроводу по дну Балтійського моря "Північний потік 2", у сукупності дві нитки "Північного потоку" матимуть потужність 55 млрд куб. м газу [7]. Для отримання в Європі дозволу та підтримки у будівництві “Північного потоку" РФ розгорнула масштабну інформаційну i дипломатичну війну проти України для переконання європейських лідерів у тому, що Україна не $\epsilon$ надійним транзитером. Наприклад, не обійшлося і без диверсій на газотранспортній інфраструктурі України. Так, 12 травня 2014 року на магістральному газопроводі Уренгой - Помари - Ужгород в Івано-Франківській області (територія, яка знаходиться за сотні кілометрів від зони АТО) стався вибух, на місці події було знайдено залишки вибухового пристрою. 17 вересня того ж року подібний вибух стався на тому ж трубопроводі у Полтавській області. Приблизно в цей час мали відбутися переговори Україна - СС щодо надійності транзиту природного газу через Україну до Європи [12]. Саме такі диверсії могли б підірвати довіру західних партнерів України і спонукати їх до пошуку альтернативних способів транспортування газу. За оцінками експертів НАК “Нафтогаз”, унаслідок запуску "Північного потоку" на повну потужність, Україна може втратити статус транзитера, а заразом майже 3 млрд дол. США на рік [8].

Унаслідок анексії АР Крим, Україною було втрачено кілька тепло-, вітро- та сонячних електростанцій, 1370 км ліній електропередач. Загальна вартість втрат НЕК "Укренерго" склала майже 1 млрд дол. США [9].

Також серйозних втрат Україна зазнала під час захоплення активів у нафтогазовій сфері. Найбільші активи належали ПАТ “ДАТ "Чорноморнафтогаз" - 10 газовидобувних стаціонарних платформ, 4 самопідйомні бурові установки, газотранспортна система 1200 км магістральних газопроводів. Було втрачено можливість видобутку природного газу, нафти і газового конденсату. Потужність родовищ повинна була вийти до 2015 року на показники 5 млрд куб м газу на рік. Усього в акваторії Чорного моря вміст родовищ природного газу оцінюються в 7 трлн куб м [10].

На окупованих територіях Донецької і Луганської областей залишилося майже $50 \%$ всього видобутку вугілля та $100 \%$ антрациту, що призвело до дефіциту антрацитового вугілля i Україна була змушена його імпортувати з інших країн, зокоема і з РФ [11].

За умов економічної кризи, пов'язаної з “гібридною війною" РФ проти України у 2014 році було вкрай складно організувати фінансову i економічну підтримку заходів щодо протидії гібридним загрозам. На потреби національної оборони виділялося $1,7 \%$ від ВВП, що в натуральному виразі складало близько 27 млрд грн. Цього було недостатньо, щоб задовольнити навіть мінімально необхідні потреби ЗС України.

Збройний конфлікт з РФ показав, що заходи протидії гібридній війні, потребують значного економічного і фінансового ресурсу. Важливою складовою у сфері забезпечення національної оборони України є iї бюджетна політика. В Указі Президента України Про рішення Ради національної безпеки і оборони України від 2 вересня 2015 року "Про нову редакцію Воєнної доктрини України” [14] 
вказується, що для досягнення цілей Воєнної доктрини загальний обсяг видатків на оборону має становити не менше $3 \%$ запланованого обсягу валового внутрішнього продукту на відповідний рік. У 2018 році на оборону було виділено 2,74\% від ВВП [15], недофінансування $0,26 \%$ ВВП, що склало у натуральному виразі 925 млн грн. У 2019 році на оборону виділено 2,58 \% від ВВП [16], згідно 3 прогнозованим показником ВВП на 2019 рік. Оборонний сектор у 2019 році недоотримав 0,42 \% або у натуральному виразі приблизно 1,5 млрд грн, щоб вийти на мінімальні нормативні показники - $3 \%$ від ВВП. Це означає, що ослаблена національна економіка не в змозі забезпечити мінімально необхідні потреби національної оборони для протидії “гібридній війні”.

Украй важливим є забезпечення гарантованого фінансування потреб сектору оборони не менше 3 \% від запланованого ВВП на поточний рік 3 подальшим допустимо можливим збільшенням частки оборонних витрат у річному бюджеті України. Це можливо тільки у разі сталого зростання національної економіки, що відповідно призведе до збільшення розмірів державного бюджету. Згідно Постанови КМ України від 23 жовтня 2019 р. № 883 "Про внесення змін у додаток до постанови Кабінету Міністрів України від 15 травня 2019 р. № 555” [22], за оптимістичним варіантом прогнозу, зростання ВВП у 2020 році складе 4,8\%, у 2021 році $5,5 \%$ i y 2022 на $6,5 \%$, що дасть змогу поступово нарощувати видатки на потреби національної оборони.

Необхідно відзначити, що разом 3 обсягом оборонних витрат велике значення має структура оборонного бюджету. Негативним показником є те, що видатки на національну оборону переважно складалися 3 видатків на утримання ЗС України. Так у період з 2010 по 2013 рік на утримання виділялося $90 \%$ оборонного бюджету i тільки $10 \%$ на підготовку військ та закупівлю, ремонт і модернізацію ОВТ. 3 початком війни розподіл оборонних видатків дещо змінився. У 2019 році утримання Збройних Сил у загальному обсязі видатків складає приблизно $80 \%$, а закупівля, модернізація і ремонт ОВТ 16,5\%. Такий розподіл $є$ дещо кращим, але не відповідає сучасним гібридним загрозам. Наприклад, у країнах-членах НАТО більш ніж $75 \%$ оборонного бюджету виділеного на споживання $є$ критичною межею. Західні воєнні експерти вважають, що оптимальний розподіл оборонного бюджету має бути таким: особовий склад - $50 \%$, поточні витрати (експлуатація та обслуговування озброєння та військової техніки) - 25 \%, капітальні витрати (фінансування науково-дослідних і дослідноконструкторських робіт, закупівля озброєння та військової техніки) - $25 \%$ [18].

Слід зазначити, що навіть існуюче обмежене фінансування сектору оборони не завжди використовується ефективно. За даними просктного офісу реформ МО України у 2018 році частка таємних закупівель перевищила 50 \% від загальної вартості закупівель. Такі показники суперечать вимогам Стратегічного оборонного бюлетеня. У завданні 2.5.1 Стратегічного оборонного бюлетеня передбачено підготовку змін до законодавства, які б забезпечили розширення сфери публічних закупівель звичайного озброєння та техніки. Зокрема, це суперечить міжнародним домовленостям, законодавству ЄС та країн-членів НАТО, де таємні закупівлі від загального обсягу складають від 5 до $10 \%$. Для порівняння, частка таємних закупівель у Німеччині, станом на 2016 рік, не перевищувала $1 \%$, у Болгарії - 2 \%, у Департаменті оборони США $-16 \%$ [19].

Однією 3 ключових проблем у забезпеченні Збройних Сил України $\epsilon$ неможливість оборонно-промислового комплексу (ОПК) України задовольнити потреби у сучасному озброєнні та військовій техніці. В основному це пов'язано зі зносом основних виробничих фондів, застарілими технологіями, часто неможливістю випуску продукції замкнутого циклу (як правило випуск ОВТ здійснювався в кооперації 3 підприємствами РФ), втратою значної частини підприємств ОПК унаслідок анексії Криму та окупації деяких районів Донецької та Луганської областей, а також нестачі кваліфікованих і професійних кадрів. Також цей процес ускладнює заборона підприємствам ОПК проводити експортноімпортні операції для закупівлі (продажу) за кордоном сировини, матеріалів, комплектувальних виробів необхідних для виробництва ОВТ. На сьогодні підприємства не мають можливості виходити на зовнішній ринок без посередника - "Укрспецекспорту" [20], що також відтягуе значні ресурси i призводить до збільшення вартості військової продукції та заважає трансферу технологій i кооперації 3 ОПК провідних країн-членів HATO та EC.

Загрозливою ситуацією $є$ те, що РФ використовує військово-морську та 
правоохоронну діяльність для перекриття морських шляхів України. Блокада Азовського моря є небезпечною для портових міст таких, як Маріуполь та Бердянськ. У портах працюють тисячі людей, також через них іде великий обсяг товарообігу. Зайвий день простою власнику товарного судна коштує від 5 до 15 тис. дол. США [20]. Це все негативно впливає як на соціально-економічну ситуацію в цих містах, на репутацію портів серед товароперевізників, так i на економічне становище в країні.

Кораблі чорноморського флоту РФ продовжують заходити до територіальних вод України, порушуючи до того ж міжнародне морське право. Чорноморський шельф багатий на поклади природного газу, але існуюча постійна загроза 3 моря не дає змоги державі реалізувати програми щодо його розроблення i гарантувати безпеку інвесторам. Саме розроблення шельфу могло б допомогти зменшити залежність України від імпортних поставок газу та підвищити свою енергетичну безпеку.

РФ, 3 допомогою Чорноморського Флоту, посилює економічний тиск України на Чорному морі через перекриття морських сполучень. Так, 19 серпня 2019 року було перекрито майже чверть Чорного моря загальною площею 436402 кв. км., що негативно вплинуло на функціонування морських торгових шляхів України [20-22].

Україна не в змозі самотужки протидіяти провокаціям РФ на морі. Військово-Морські Сили України, на які покладено зокрема забезпечення безпеки на морських шляхах, 3 окупацією Криму втратили значну частину боєздатності, для відновлення якої необхідний значний фінансовий ресурс i час. Можна спрогнозувати, що надалі економічний тиск на Україну тільки посилюватиметься, завдаючи ще більших економічних втрат, відповідно негативно впливаючи на фінансові можливості, а отже і на видатки на національну оборону.

\section{Висновок}

та напрям

подальших

досліджень.

Аналізуючи

викладене пропонуємо:

привести структуру оборонного бюджету України, до прийнятних структур бюджету сектору оборони країн-членів НАТО 3 таким розподілом видатків персонал - не більше $65 \%$; експлуатаційні витрати (у т. ч. обслуговування озброєння та військової техніки) - не менше $15 \%$, капітальні витрати (інфраструктура, фінансування науководослідних і дослідно-конструкторських робіт, закупівля озброєння та військової техніки) - не менше 20 \%. Для досягнення такого показника необхідно забезпечити видатки на національну оборону у розмірі 3 \% від ВВП, що згідно 3 прогнозованими показниками росту ВВП на 2020 рік має скласти 137,96 млрд грн;

зменшити частку таємних закупівель, що призведе до зростання ролі громадського контролю над сферою державних закупівель у секторі оборони та допоможе якісніше контролювати закупівлі та виявляти порушення і зловживання;

зняти обмеження по експортноімпортним операціям - це дасть змогу тіснішої кооперації 3 підприємствами ОПК країнчленів НАТО, швидшого трансферу технологій i зменшить державний вплив на формування політики підприємств;

прийняти досвід США та впровадити співвідношення $\quad 0,4 \% \quad$ від загального оборонного бюджету України або 410 млн грн (у 2019 році) на НДДКР.

Для забезпечення економічної безпеки на Чорному та Азовському морях від гібридної агресії 3 боку РФ необхідно оптимізувати роботу щодо будівництва корабельного складу ВМС ЗС України через збільшення держзамовлення на підприємствах ОПК України та закупівлі кораблів у державпартнерів.

\section{СПИСОК ВИКОРИСТАНОЇ ЛІТЕРАТУРИ}

1. Магда Е.В. Гибридная война: выжить и победить. Харьков : Виват, 2015. с. 29.

2. Лещенко О. Я. "Гібридна війна" як науковий конструкт: проблеми пошуку термінологічної та концептуальної сутності. Епістемологічні дослідження в філософії, сочіальних $i$ політичних науках, (6), 60-71. (2016). URL: https://visnukpfs.dp.ua /index.php/PFS/article/view/853 (дата звернення: 07.08.2019)

3. О внесении изменений в Указ Президента Российской Федерации от 1 января 2016 г. № 1 O мерах по обеспечениюэкономическойбезопасности национальных интересов Российской Федерации при осуществлении международных транзитних перевозок грузов с территории Украины на территорию Республики Казахстан через территорию Российской Федерации: Указ президента Российской Федерации от 01.07.2016 № 319 URL: http://publication.pravo.gov.ru/

Document/View/0001201607030001 (дата звернення: 15.08.2019).

4. Світова гібридна війна: український фронт : монографія / за заг. ред. В. П. Горбуліна. Національний інститут стратегічних досліджень. К.: НІСД, 2017. 496 с. ст. 287.

5. О приостановлении Российской Федерацией действий Договора о зоне свободной торговли в отношении Украины: Указ президента РФ от 16.12.2015 № 628 URL: http://publication.pravo.gov.ru/ Document/View/ 0001201512160035\#print (дата звернення: 10.08.2019).

6. Кулицький С. Економічна складова гібридної війни Росії проти України. Центр досліджень соціальних 
комунікацій НБУВ. URL: http://nbuviap.gov.ua/ index.php?option=com_content $\&$ view $=$ article $\&$ id $=$ 2433:gibridna-vijna-ekonomichnijaspekt\&catid=8\&Itemid=350. (дата звернення: 20.08.2019)

7. Коболєв пояснив, що може втратити Україна в разі запуску "Північного потоку-2". URL: https://uazmi.org/ news/post/eFIqlIzIaN6lkYKmUBVgwm (дата звернення: 01.09.2019)

8. "Укренерго" оцінює вартість втрачених активів у Криму в \$80-900 мільйонів. URL: http://economics.unian.ua/energetics/1529388- ukrenergootsinyue- vartist- vtrachenih- aktiviv- ukrimu-v- 800- 900milyoniv.html (дата звернення: 25.08.2019).

9. Через анексію Криму втрати України у ПЕК оцінюють у $\$ 300$ млрд - Продан. URL: http://dt.ua/ECONOMICS/cherez- aneksiyu- krimu- vtratiukrayini- u- pek- ocinyuyut- u- 300-mlrd- prodan147653_.html (дата звернення: 10.08.2019).

10. Україна у 2014 році імпортувала вугілля на $\$ 1,8$ млрд. URL: http://economics.unian.ua/energetics/ 1031951ukrajina- u- 2014- rotsi- importuvala- vugillya- na- 18 mlrd.html (дата звернення: 10.08.2019).

11. У Карпатах на газопроводі сталося три вибухи. Основна версія інциденту - теракт. URL: http://tyzhden.ua/News/109919. (дата звернення: 19.08.2019).

12. Валовий внутрішній продукт (ВВП) в Україні 2019. Мінфін.

URL: https://index.minfin.com.ua/ua/economy/gdp/ (дата звернення: 14.09.2019)

13. Бюджетний кодекс України : Закон України від 07.10 2010 p. №2592-IV. Ст 87.
14. Про нову редакцію Воєнної доктрини України : Указ Президента України від 24.09.2015 року № 555/2015.Законодавство України. 2015.

15. Про Державний бюджет України на 2018 рік : Закон України від 07.12.2017 р. № 2246-VIII. Законодавство України. 2017.

16. Про Державний бюджет України на 2019 рік : Закон України від 23.11.2018 р. № 2629-VIII. Законодавство України. 2018.

17. Телюк К.Ф. Фінансування національної оборони України. Вісник університету банківської справи. 2015. №1. C.74-76.

18. NAKOURL. URL: https://nako.org.ua/news/uminoborony-obitsyayut-zbilshyty-tajemnu-chastkuoboronnoho-byudzhetu/ (дата звернення: 20.09.2019).

19. Про створення Держаної компанії 3 експорту та імпорту продукції i послуг військового та спеціального призначення: Постанова Кабінету Міністрів України від 14.08.1996 р. № 944.

20. Анастасія Зануда ВBC News Україна Скільки коштуватиме Україні блокада Азова?. URL: https://www.bbc.com/ukrainian/features-45321862 (дата звернення: 20.09.2019).

21. Про внесення змін у додаток до постанови Кабінету Міністрів України від 15 травня 2019 р. № 555 : Постанова Кабінету Міністрів України від 23.10.2019 p. № 883 .

22. Бега В. Росія 324 липня перекрила п’ять районів Чорного моря, сумарною площею 118570 км$^{2}$, що становить понад чверть його загальної площі у 436402 км$^{2}$. URL: https://hromadske.ua/posts/rosiya-perekrilaponad-chvert-chornogo-morya (дата звернення: 21.10.2019).

Стаття надійшла до редакції 08.11.2019

Ткач Н. Я., канд. техн. наук, ст. науч. сотр. ${ }^{1}$;

Бойко Р. В., канд. техн. наук, ст. науч. сотр. ${ }^{2}$;

Лойшин А. А. ${ }^{1}$; Бойко В. А. канд. экон. наук, ст. науч. сотр. ${ }^{2}$

1 - Национальный университет обороны Украины имени Ивана Черняховского, Киев;

2 - Центр военно-стратегических исследований Национального университета обороны Украины имени Ивана Черняховского, Киев

Рекомендации по финансовому и экономическому обеспечению потребностей национальной обороны в ходе противодействия гибридной войне

Резюме. В статье проведен анализ экономического давления, как одной из составляющих гибридной войны Российской Федерации против Украины. Раскрыта сущность экономического давления, который начался задолго до горячей фазы конфликта и доказано, что его главной целью была остановка интеграции Украины с ЕС и НАТО. Показано влияние вооруженной агрессии и оккупации части территории Украины на ее макроэкономическую стабильность. Раскрыто проблематику экономического и финансового обеспечения потребностей национальной обороны и даны предложения по ее усовершенствованию в условиях гибридной войны.

Ключевые слова: гибридная война; ресурсы; финансовое и экономическое обеспечение; уровень инфляции; безопасность.

\section{Tkach, PhD (Technical), senior researcher ${ }^{1}$; A. Loishyn ${ }^{1}$; \\ R. Boiko, PhD (Technical), senior researcher ${ }^{2}$; \\ V. Boiko, PhD (Economic), senior researcher ${ }^{2}$}

1 - The National Defence University of Ukraine named after Ivan Cherniakhovskyi, Kyiv

2 - Center for Military and Strategic Studies of the National Defence University of Ukraine named after Ivan Cherniakhovskyi, Kyiv

\section{Recommendations for financial and economic care of national defense needs in the process} of hybrid war

Resume. The article analyzes the economic pressure as one of the components of the hybrid war of the Russian Federation against Ukraine. The essence of economic pressure, which began long before the hot phase of the conflict, is revealed, and its main purpose was to stop the integration of Ukraine with the EU and NATO. The influence of armed aggression and occupation of part of the territories of Ukraine on its macroeconomic stability is shown. The problems of economic and financial support to the needs of national defense are presented and suggested for their improvements in the conditions of hybrid war are presented.

Keywords: hybrid war; resources; financial and economic support; inflation rate; security. 